\author{
(c) (1) (8) \\ Jurnal Pendidikan Dasar Indonesia is licensed under \\ A Creative Commons Attribution-Non Commercial 4.0 International License
}

\title{
Pengaruh Model Pembelajaran POE (Predict, Observe and Explain) Terhadap Keterampilan Proses Sains Siswa SD Kelas V ditinjau dari Keterampilan Metakognitif
}

\author{
Erdi Guna Utama \\ STKIP Singkawang, Kalimantan Barat \\ E-mail: erdi.guna.utama@gmail.com
}

\begin{abstract}
Abstrak: Penelitian ini bertujuan untuk menyelidiki pengaruh model pembelajaran POE (Predict, Observe and Explain) terhadap keterampilan proses sains siswa SD kelas V ditinjau dari keterampilan metakognitif. Penelitian ini tergolong penelitian eksperimen semu dengan rancangan pretest-posstest non equivalent control group design. Populasi dalam penelitian ini adalah seluruh kelas V SD di Gugus 8 Kota Singkawang. Pengambilan sampel pada penelitian ini menggunakan teknik random sampling. Sampel terbagi dalam dua kelompok yaitu kelompok eksperimen dan kelompok control. Kelompok eksperimen adalah kelas yang dibelajarkan dengan model pembelajaran $P O E$ dan kelompok kontrol adalah kelas yang dibelajarkan dengan model pembelajaran konvensional. Data dalam penelitian ini dikumpulkan dengan menggunakan tes untuk keterampilan proses sains dan menggunakan kuesioner untuk keterampilan metakognitif. Data dianalisis dengan menggunakan analisis varians dua jalur dan uji tuckey. Hasil penelitian menunjukkan bahwa: 1) terdapat perbedaan yang signifikan keterampilan proses sains antara siswa yang mengikuti pembelajaran dengan model pembelajaran POE dan siswa yang mengikuti pembelajaran secara konvensional $(\mathrm{FA}=35,09 ; \mathrm{p}<0,05) ; 2)$ terdapat pengaruh interaksi yang signifikan antara model pembelajaran POE dan keterampilan metakognitif terhadap keterampilan proses sains siswa $(\mathrm{FAB}=7,759 ; \mathrm{p}<0,05) ; 3)$ pada siswa yang memiliki keterampilan metakognitif tinggi, terdapat perbedaan signifikan keterampilan proses sains antara siswa yang mengikuti pembelajaran dengan model pembelajaran POE dan siswa yang mengikuti pembelajaran konvensional $(\mathrm{Q}=8,79 ; \mathrm{p}<0,05) ; 4)$ pada siswa yang memiliki keterampilan metakognitif rendah, tidak terdapat perbedaan signifikan keterampilan proses sains antara siswa yang mengikuti pembelajaran dengan model pembelajaran POE dan siswa yang mengikuti pembelajaran konvensional $(\mathrm{Q}=3,17 ; \mathrm{p}>0,05)$
\end{abstract}

Kata Kunci: $P O E$; Keterampilan Metakognitif; Keterampilan Proses Sains

\section{Pendahuluan}

Pembelajaran IPA (Ilmu Pengetahuan Alam) bertujuan untuk membantu siswa agar mampu menguasai pengetahuan tentang keteraturan sains [1]. Pengetahuan tersebut diperoleh melalui proses-proses ilmiah sehingga dapat menumbuhkan sikap ilmiah siswa yang dapat digunakan untuk memecahkan masalah dalam kehidupan sehari-hari.

IPA hakikatnya terdiri atas produk, proses, dan sikap [2]. Berdasarkan hakikat IPA di atas, maka pembelajaran IPA hendaknya menitik beratkan pada tiga kompetensi, yaitu kompetensi IPA sebagai proses, kompeten-si IPA sebagai produk dan kompetensi IPA sebagai sikap. Ketiga ranah kompetensi IPA ini tidak dapat dipisahkan yang berarti dalam pembelajarannya harus menjadi satu kesatuan

Kompetensi IPA sebagai produk merujuk pada pengetahuan siswa akan produk sains. Hal ini bermakna bahwa pembelajaran IPA sekolah dasar harus dapat meningkatkan pengetahuan dan pemahaman siswa tentang produk sains yang berupa fakta, konsep, lambang, konsepsi, teori, atau penjelasan yang dimuat dalam bahan ajar, buku teks, artikel ilmiah, makalah dsb [3]. Kompetensi IPA sebagai sikap merujuk pada sikap yang diperlihatkan oleh para ilmuwan saat mereka melakukan berbagai kegiatan ilmiah terkait dengan profesinya sebagai ilmuwan. Sikap ini disebut dengan sikap ilmiah. Dalam pembelajaran IPA di sekolah dasar, kompetensi sikap yang dimaksud yakni sikap ingin tahu,percaya diri, jujur, tidak tergesa-gesa, dan objektif terhadap fakta [4], sedangkan kompetensi IPA sebagai proses diartikan bahwa siswa dituntut untuk memiliki dan mengembangkan keterampil-an proses sains.

Keterampilan proses adalah keterampilan yang digunakan ketika pembelajaran sains [5]. Keterampilan proses sains (KPS) adalah kemampuan siswa untuk menerapkan metode ilmiah dalam memahami, mengembangkan dan menemukan ilmu pengetahuan khususnya pada pembelajaran sains dengan tujuan untuk 
mengoptimalkan proses belajar mengajar yang ingin dicapai [2].

Menurut peraturan Menteri Pendidikan Nasional Nomor 41 tahun 2007 tentang Standar Proses [6] "Setiap guru pada satuan pendidikan berkewajiban menyusun RPP (rencana pelaksanaan pembelajaran) secara lengkap dan sistematis agar pembelajaran berlangsung secara interaktif, inspiratif, menyenangkan, menantang, memotivasi peserta didik untuk berpartisipasi aktif, serta memberikan ruang yang cukup bagi prakarsa, kreativitas, dan kemandirian sesuai dengan bakat, minat dan perkembangan fisik serta psikologis peserta didik".

Mengacu pada standar proses pembelajaran IPA di SD diharapkan dapat membuat siswa menguasai konsep IPA, memiliki sikap ilmiah serta memiliki keterampilan proses sains sehingga menjadi modal awal dan modal dasar mereka sebelum mereka menerima matapelajaran Fisika, Kimia dan Biologi yang akan didapatkan pada jenjang pendidikan selanjutnya.

Pembelajaran IPA di sekolah dasar menjadi sangat penting bagi siswa sebagai dasar pengetahuan mereka, namun pada kenyataanya di lapangan, sebagian besar siswa SD di Indonesia belum menguasai konsep IPA dan belum mampu mengaplikasikan konsep tersebut dalam kehidupan nyata. Hal ini mengacu pada rendahnya kualitas pendidikan IPA Indonesia dalam kompetensi sains dan matematika yang ditunjukkan berdasarkan peringkat TIMSS (Trends in International Mathematics and Science Study) tahun 2015 [7], Menurut hasil survey TIMSS skor rata-rata literasi sains siswa kelas 4 SD Indonesia berada pada posisi 44 dari 47 negara. Selain itu rendah-nya kualitas pendidikan Indonesia juga ditunjukkan pada peringkat PISA (Programme for International Student Assesment) yang memposisikan Indonesia pada peringkat 64 dari 72 negara OECD [8].

Rendahnya literasi sains dalam peringkat ini menunjukkan bahwa pembelajaran IPA di Indonesia belum terlaksana dengan baik. Hal ini disebabkan karena adanya kesenjangan antara pelaksanaan pembelajaran IPA dengan standar proses pada kurikulum KTSP. Guru pada umumnya belum dapat membuat perangkat pembelajaran dengan baik, selain itu guru belum dapat melaksanakan pembelajaran sesuai dengan rencana pelaksanaan yang telah disusun dan pengelolaan kelas dilakukan secara konvensional sehingga tidak memungkin-kan terjadinya interaksi antar siswa.

Sebagian besar guru hanya menyampaikan sains sebagai produk dan peserta didik menghafal informasi faktual [9]. Hal ini diperkuat oleh pernyataan [10] yang mengatakan bahwa pencapaian prestasi belajar di Indonesia di bidang sains dan matematika rendah karena pembelajaran hanya menekankan kepada kemampuan menghafal. Pembelajaran yang menekankan pada kemampuan menghafal tentu tidak akan efektif untuk mengembangkan keterampilan proses dan kognitif berpikir siswa.

Belajar akan lebih bermakna, berguna, dan mudah diingat siswa bila mereka memfokuskan diri untuk memahami struktur subjek yang sedang dipelajari [11]. Sejalan dengan pemikiran Bruner tersebut, [12] menambahkan bahwa pengajaran yang baik harusnya mampu melibatkan siswa secara aktif dalam pembelajaran, memberikan pengalaman-pengalaman yang menguji pemikiran dan memaksa mereka untuk menyusun ulang keyakinan-keyakinannya.

Salah satu model pembelajaran yang menekankan kepada pembelajaran konseptual dan sesuai dengan hakikat IPA adalah model pembelajaran POE (Predict, Observe and Explain). Model pembelajaran ini melibatkan kegiatan eksperimen dan langkah-langkah pembelajarannya disusun secara sistematik dengan metode ilmiah sehingga dapat meningkatkan penguasaan konsep dan sikap ilmiah siswa serta mampu mengembangkan keterampilan berpikir dan berproses siswa.

Model pembelajaran POE (Prediction, Observation, Explanation) merupakan salah satu model pembelajaran yang dikembangkan untuk menemukan kemampuan siswa dalam memprediksi suatu fenomena alam serta alasan mereka dalam membuat prediksi tersebut [13]. Sedangkan menurut pendapat [14], Model pembelajaran POE (Predict, Observe and Explain) adalah model pembelajaran dengan urutan proses membangun pengetahuan dengan terlebih dahulu meramalkan solusi dari permasalahan, lalu melakukan eksperimen atau observasi.

Penelitian [15] menemukan bahwa terdapat perbedaan pemahaman konsep dan sikap ilmiah siswa yang belajar dengan model pembelajaran POE dan yang belajar dengan model konvensional. Model pembelajaran POE memberikan nilai pemahaman konsep fisika dan sikap ilmiah siswa yang lebih baik dibandingkan model pembelajaran konvensional.

Pembelajaran POE dapat membantu siswa mengeksplorasi dan menilai sendiri ide yang mereka ungkapkan, terutama pada kegiatan memprediksi dan bernalar. Jika pada tahapan observasi dapat menunjukkan hasil yang berbeda dengan prediksi awal mereka, maka konsep awal kognitif mereka dapat direkonstruksi ulang dan direvisi kembali sehingga menghasilkan pengetahuan baru yang lebih kredibel dan bermakna.

Model pembelajaran POE meng-gunakan langkahlangkah pembelajaran sistematis melalui metode ilmiah yang melibatkan proses-proses kognitif siswa sehingga dalam penerapan model pembelajaran POE, guru tidak dapat mengabaikan kemampuan siswa dalam mengolah kognisinya. Keterampilan siswa dalam mengolah dan memanfaatkan kognisinya dinamakan keterampilan metakognitif.

Keterampilan metakognitif (metacognitive skills) didefinisikan sebagai kesadaran seseorang dalam mengontrol dan mengendalikan proses kognitifnya sendiri [16]. Sedangkan berdasarkan pendapat [17] menyatakan bahwa keterampilan metakognitif merupakan keterampilan menggunakan strategi metakognitif dalam menyelesaikan suatu masalah.

Dari pernyataan Flavell tersebut maka ditemukan bahwa, tingkat keterampilan metakognitif siswa turut berperan dalam keberhasilan pembelajaran terutama pembelajaran yang berbasis penyelesaian masalah. Namun 
selama ini keterampilan metakognitif siswa belum mendapat perhatian yang maksimal.

Berdasarkan pemikiran diatas, maka peneliti terdorong untuk melakukan studi yang bertujuan untuk menyelidiki pengaruh model pembelajaran POE (Predict, Observation and Explain) terhadap keterampilan proses sains siswa SD kelas V ditinjau dari keterampilan metakognitif. Terdapat 4 pertanyaan penelitian yang dijawab dalam penelitian ini, yaitu:1) apa-kah terdapat perbedaan keterampilan proses sains antara siswa yang mengikuti pembelajaran dengan model pembelajaran POE dan siswa yang mengikuti pembelajaran secara konvensional?; 2) apakah terdapat pengaruh interaksi antara model pembelajaran POE dengan keterampilan metakognitif terhadap keterampilan proses sains siswa?; 3) pada siswa yang memiliki keterampilan metakognitif tinggi, apakah terdapat perbedaan signifikan keterampilan proses sains antara siswa yang mengikuti pembelajaran dengan model pembelajaran POE dan siswa yang mengikuti pembelajaran konvensional?; 4) pada siswa yang memiliki keterampilan metakognitif rendah, apakah terdapat perbedaan signifikan keterampilan proses sains antara siswa yang mengikuti pembelajaran dengan model pembelajaran POE dan siswa yang mengikuti pembelajaran konvensional ?

\section{Metode Penelitian}

Penelitian ini merupakan penelitian kuasi eksperimen dengan pola dasar "pretest-posstest non equivalent control group design" dengan desain eksperimen yang digunakan adalah desain group faktorial $2 \times 2$. Terdapat tiga variabel dalam penelitian ini, yaitu: 1) variabel terikat dalam penelitian ini adalah keterampilan proses sains; 2) variabel bebas perlakuan adalah model pembelajaran yang dibedakan menjadi dua kelompok, yaitu model pembelajaran $P O E$ dan pembelajaran konvensional; 3) variabel moderator adalah keterampilan metakognitif, yang dibedakan menjadi dua kelompok, yaitu keterampilan metakognitif tinggi dan keterampilan metakognitif rendah

Populasi dalam penelitian ini adalah seluruh kelas V SD Gugus 8 Singkawang tahun pelajaran 2016/2017. Jumlah siswa kelas V SD di gugus 8 berjumlah 166 siswa. Pada penelitian ini, teknik pemilihan sampel yang digunakan adalah teknik Random sampling/sampling kelompok acak. Teknik ini digunakan sebagai teknik pengambilan sampel karena individu-individu pada populasi telah terdistribusi ke dalam kelas-kelas sehingga tidak memungkinkan untuk melakukan pengacakan terhadap individu-individu dalam populasi. Sampel yang didapatkan lalu diacak kembali untuk menentukan kelas eksperimen dan kelas kontrol.

Data tentang keterampilan proses sains dikumpulkan melalui tes keterampilan proses sains yang terdiri dari soal pilihan ganda dengan indeks reliabilitas sebesar 0,87 dan soal uraian, dengan indeks reliabilitas sebesar 0,87 . Sementara itu, data tentang keterampilan metakognitif dikumpulkan dengan kuesioner dengan indeks reliabilitas sebesar 0,84 .
Data dianalisis dengan teknik deskriptif dan ANAVA dua jalur dengan rancangan analisis varians seperti pada tabel 1 .

Tabel 1 Rancangan Analisis Varians Faktorial 2 x 2

\begin{tabular}{|l|c|c|}
\hline $\begin{array}{l}\text { Keterampilan } \\
\text { metakognitif (B) }\end{array}$ & $P O E(\mathrm{Al})$ & $\begin{array}{c}\text { Konvensional } \\
\text { (A2) }\end{array}$ \\
\hline $\begin{array}{l}\text { Keterampilan } \\
\text { metakognitif Tinggi } \\
(\mathrm{B} 1)\end{array}$ & A1B1 & A1B1 \\
\hline $\begin{array}{l}\text { Keterampilan } \\
\text { metakognitif Rendah } \\
(\mathrm{B} 2)\end{array}$ & A1B2 & A2B2 \\
\hline $\begin{array}{l}\text { Total } \\
\text { Ketal }\end{array}$ & A1B1+ A1B2 & $\begin{array}{c}\text { A1B1 }+ \\
\text { A2B2 }\end{array}$ \\
\hline
\end{tabular}

Keterangan:

A1 = Model Pembelajaran POE

A2 = Model Pembelajaran Konvensional

B1 = Keterampilan metakognitif Tinggi

B2 = Keterampilan metakognitif Rendah

Untuk mengeliminasi efek plapon, data yang dianalisis adalah data gain skor ternormalisasi yang diperoleh dari rumus

$$
g=\frac{S_{f}-S_{i}}{S_{m}-S_{i}}
$$

(Hake dalam Suma, 2010)

Keterangan :

$$
\begin{aligned}
& g=\text { Gain yang dinormalisasi (N-gain) } \\
& \begin{array}{l}
S_{m}=\text { Skor maksimum (ideal ) dari pre-test dan post }- \\
\quad \text { test }
\end{array} \\
& S_{f}=\text { Skor } \text { post-test } \\
& S_{f}=\text { Skor pre-test }
\end{aligned}
$$

\section{HASIL PENELITIAN DAN PEMBAHASAN} Hasil

Deskripsi data rerata gain skor keterampilan proses sains siswa yang mendapat pembelajaran model $P O E$ dan model pembelajaran konvensional, disajikan pada Tabel 2.

Tabel 2. Deskripsi Sebaran N-Gain KPS pada Kelompok Eksperimen dan Kelompok Kontrol

\begin{tabular}{|l|c|c|}
\hline \multicolumn{1}{|c|}{ Uraian } & $\begin{array}{c}\text { Kelompok } \\
\text { Eksperimen }\end{array}$ & $\begin{array}{c}\text { Kelompok } \\
\text { Kontrol }\end{array}$ \\
\hline Nilai Tertingi & 0,778 & 0,625 \\
\hline Nilai Terendah & 0,200 & 0,143 \\
\hline Rata-rata & 0,481 & 0,380 \\
\hline Standar Deviasi & 0,147 & 0,112 \\
\hline Kualifikasi & Sedang & Sedang \\
\hline
\end{tabular}

Pada tabel 2, dapat dilihat bahwa rata-rata gain skor kelompok eksperimen lebih baik daripada kelompok kontrol. 
Hal ini menunjukkan bahwa keterampilan proses sains siswa yang dibelajarkan dengan model pembelajaran $P O E$ lebih baik dibandingkan siswa yang dibelajarkan dengan pembelajaran konvensional.

Deskripsi data rerata gain skor keterampilan proses sains siswa yang mendapat pembelajaran model $P O E$ dan model pembelajaran konvensional berdasarkan tingkat keterampilan metakognitifnya, disajikan pada Tabel 3.

Tabel 3. Deskripsi Sebaran N-Gain KPS Berdasarkan Model Pembelajaran dan Keterampilan Metakognitif

\begin{tabular}{|l|c|c|c|c|}
\hline \multirow{2}{*}{ Uraian } & \multicolumn{2}{|c|}{$\begin{array}{c}\text { Kelompok } \\
\text { Eksperimen }\end{array}$} & \multicolumn{2}{c|}{ Kelompok Kontrol } \\
\cline { 2 - 5 } & KMT & KMR & KMT & KMR \\
\hline $\begin{array}{l}\text { Nilai } \\
\text { Tertinggi }\end{array}$ & 0,778 & 0,529 & 0,625 & 0,500 \\
\hline $\begin{array}{l}\text { Nilai } \\
\text { Terendah }\end{array}$ & 0,286 & 0,200 & 0,278 & 0,143 \\
\hline Rata-rata & 0,596 & 0,366 & 0,447 & 0,312 \\
\hline $\begin{array}{l}\text { Standar } \\
\text { Deviasi }\end{array}$ & 0,102 & 0,079 & 0,087 & 0,092 \\
\hline Kualifikasi & Sedang & Sedang & Sedang & Sedang \\
\hline
\end{tabular}

Keterangan :

$\begin{array}{ll}\text { KMT } & \text { : Keterampilan Metakognitif Tinggi } \\ \text { KMR } & : \text { Keterampilan Metakognitif Rendah }\end{array}$

Pada tabel 3, dapat dilihat bahwa rata-rata gain skor KPS siswa yang memiliki keterampilan metakognitif tinggi lebih baik dibandingkan siswa yang memiliki keterampilan metakognitif rendah, baik pada siswa yang dibelajarkan dengan model pembelajaran $P O E$ maupun siswa yang dibelajarkan dengan model pembelajaran konvensional.

\section{Pengujian Hipotesis dan Pembahasan}

Terdapat 4 hipotesis yang diuji dalam penelitian ini, yaitu:

Hipotesis 1

$\mathrm{H}_{0}=$ Tidak terdapat perbedaan yang signifikan keterampilan proses sains antara siswa yang mengikuti pembelajaran dengan model pembelajaran POE dan siswa yang mengikuti pembelajaran secara konvensional

$\mathrm{H}_{1}=$ Terdapat perbedaan yang signifikan keterampilan proses sains antara siswa yang mengikuti pembelajaran dengan model pembelajaran POE dan siswa yang mengikuti pembelajaran secara konvensional

Hipotesis 2

$\mathrm{H}_{0}=$ Tidak terdapat pengaruh interaksi yang signifikan antara model pembelajaran POE dan keterampilan metakognitif terhadap keterampilan proses sains siswa

$\mathrm{H}_{1}=$ Terdapat pengaruh interaksi yang signifikan antara model pembelajaran POE dan keterampilan metakognitif terhadap keterampilan proses sains siswa
Hipotesis 3

$\mathrm{H}_{0}=$ Pada siswa yang memiliki keterampilan metakognitif tinggi, tidak terdapat perbedaan signifikan keterampilan proses sains antara siswa yang mengikuti pembelajaran dengan model pembelajaran POE dan siswa yang mengikuti pembelajaran konvensional

$\mathrm{H}_{1}=$ Pada siswa yang memiliki keterampilan metakognitif tinggi, terdapat perbedaan signifikan keterampilan proses sains antara siswa yang mengikuti pembelajaran dengan model pembelajaran POE dan siswa yang mengikuti pembelajaran konvensional

Hipotesis 4

$\mathrm{H}_{0}=$ Pada siswa yang memiliki keterampilan metakognitif rendah, tidak terdapat perbedaan signifikan keterampilan proses sains antara siswa yang mengikuti pembelajaran dengan model pembelajaran POE dan siswa yang mengikuti pembelajaran konvensional

$\mathrm{H}_{1}=$ Pada siswa yang memiliki keterampilan metakognitif rendah, terdapat perbedaan signifikan keterampilan proses sains antara siswa yang mengikuti pembelajaran dengan model pembelajaran $\mathrm{POE}$ dan siswa yang mengikuti pembelajaran konvensional

Uji analisis anava dua jalur pada hipotesis pertama menunjukkan bahwa nilai $F_{\text {hitung }}=35,09$ dan $p<0.05$. Oleh karena itu, hipotesis $\mathrm{H}_{0}$ ditolak dan $\mathrm{H}_{1}$ diterima. Ini berarti bahwa ada perbedaan keterampilan proses sains antara siswa yang mengikuti pelajaran dengan model pembelajaran POE dan model pembelajaran konvensional. Rata-rata gain skor KPS kelompok ekperimen lebih baik daripada kelompok kontrol. Hal ini menunjukkan bahwa model pembelajaran POE lebih cocok diterapkan dibandingkan model pembelajaran konvensional dalam meningkatkan keterampilan proses sains siswa.

Pembelajaran IPA pokok bahasan cahaya dan sifatsifatnya yang dibelajarkan dengan model pembelajaran $P O E$ mampu menciptakan proses belajar mengajar yang aktif. Kegiatan-kegiatan dalam pembelajar-an mampu menstimulus siswa agar lebih berani, mandiri, komunikatif dan partisipatif, misalnya dalam menemukan dan menyampaikan hipotesis. Kemudian dalam melakukan percobaan dan kegiatan berdiskusi kelompok serta mengkomunikasikan hasil diskusi kelompoknya.

Secara keseluruhan, pembelajaran $P O E$ memberikan peran yang lebih besar bagi siswa. Siswa mengambil kendali atas keberhasilan belajarnya sendiri. Mereka belajar dengan mengkonstruks pengetahuannya sendiri dan menemukan hal yang baru sehingga siswa tampak lebih bersemangat dan termotivasi dalam kegiatan pembelajaran.

Model pembelajaran $P O E$ dapat membentuk pengetahuan IPA siswa secara mandiri sekaligus memberi pengalaman yang bermakna bagi siswa serta dapat mengembangkan kemampuan berkomuni-kasi mereka. Pada akhirnya, kegiatan-kegiatan ilmiah yang dilalui oleh siswa selama pembelajaran $P O E$ bisa berkontribusi langsung dalam meningkatnya keterampilan proses sains mereka. 
Sementara itu, pembelajaran konvensional pada kelompok yang berbeda cenderung bersifat teacher centered. Pada pembelajaran konvensional, fungsi guru lebih dominan sebagai pemberi informasi. Guru mengatur secara ketat proses pembelajaran baik dari segi topik, materi ajar, waktu, maupun strategi. Tujuan akan dicapai secara maksimal bila guru mampu mendemonstrasikan pengetahuan dan ketrampilan secara tepat hingga dapat ditiru oleh siswa. Sementara siswa hanya pasif mendengarkan penjelasanpenjelasan guru tanpa dilibatkan secara aktif dalam pembelajaran.

Karena seluruh kegiatan diatur dan berpusat kepada guru dan siswa hanya bersifat menerima secara pasif, daya nalar dan pengetahuan siswa hanya berkembang sebatas pengetahuan yang dimiliki oleh guru. Hal ini menyebabkan aktivitas siswa menjadi terbatas dan mengakibatkan siswa tidak mampu meningkatkan keterampilan proses sainsnya.

Hasil penelitian ini konsisten dengan hasil penelitian sebelumnya yang dilakukan oleh Gama dkk (2014). Penelitian yang dilakukan oleh Gama dkk menunjukkan bahwa keterampilan proses siswa yang dibelajarkan dengan pendekatan saintifik setting inkuiri lebih baik dari kelompok siswa yang dibelajarkan dengan model pembelajaran konvensional. Pendekatan saintifik inkuiri merupakan pembelajaran dengan metode-metode ilmiah dimana siswa dituntut untuk lebih aktif dalam proses penemuan.

Uji anava 2 jalur untuk hipotesis kedua diperoleh nilai $\mathrm{F}_{\mathrm{AB}}$ hitung $=7,759$ dan $\mathrm{p}<0.05$. Hasil ini menunjukkan bahwa $\mathrm{F}_{\mathrm{AB}}$ hitung signifikan. Oleh karena itu, hipotesis $\mathrm{H}_{0}$ ditolak dan $\mathrm{H}_{1}$ diterima. Jadi, dapat disimpulkan ada pengaruh interaksi antara model pembelajaran dan keterampilan metakognitif terhadap keterampilan proses sains siswa. Pola interaksi antara model pembelajaran dengan keterampilan metakognitif ditunjukkan pada gambar 1 .

Berdasarkan gambar 1, terlihat bahwa adanya konfigurasi rata-rata gain skor keterampilan proses sains siswa untuk setiap tingkat keterampilan metakognitif. Pada kelompok dengan tingkat keterampilan metakognitif tinggi, rata-rata gain skor keterampilan proses sains siswa yang mengikuti pelajaran dengan model pembelajaran $P O E$ lebih baik daripada keterampilan proses sains siswa yang mengikuti pelajaran dengan pembelajaran konvensional. Sementara itu, pada kelompok dengan tingkat keterampilan metakognitif rendah, rata-rata gain skor keterampilan proses sains siswa yang mengikuti pelajaran dengan pembelajaran model pembelajaran POE lebih baik daripada keterampilan proses sains siswa yang mengikuti pelajaran dengan konvensional.

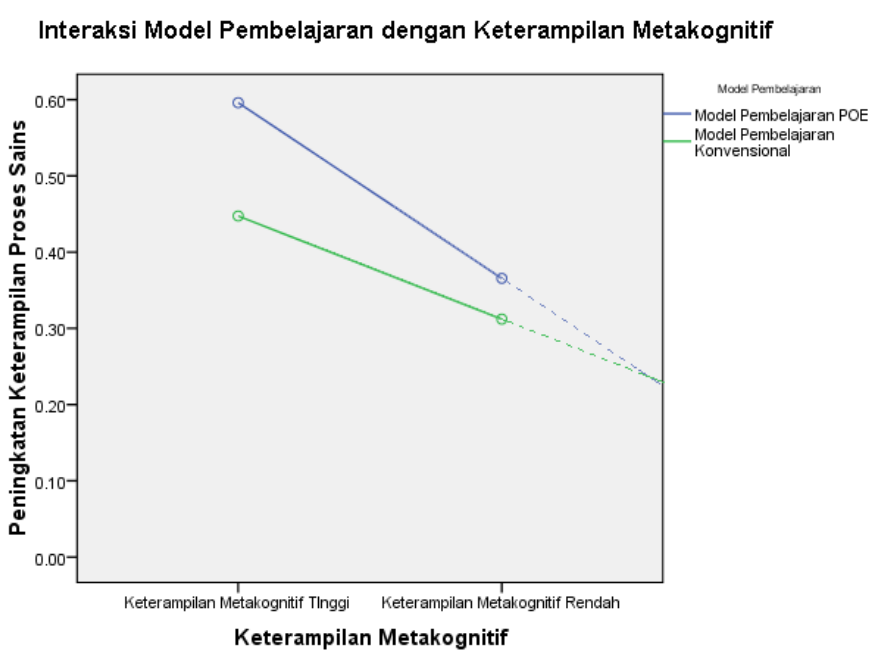

Gambar 1. Interaksi Model Pembelajaran dengan Keterampilan Metakognitif terhadap Peningkatan Keterampilan Proses Sains

Berdasarkan analisis tersebut maka dapat disimpulkan bahwa terdapat pengaruh interaksi antara model pembelajaran dengan keterampilan metakognitif terhadap keterampilan proses sains. Pengaruh interaksi antara kedua variabel terjadi dikarenakan baik model maupun keterampilan metakognitif sama-sama memiliki pengaruh yang kuat terhadap keterampilan proses sains. Perubahan peningkatan keterampilan proses sains seorang siswa dalam pembelajaran ditentukan oleh model pembelajaran maupun kemampuan individu tersebut. Oleh karena itu, model pembelajaran yang diterapkan harus disesuaikan dengan karakteristik siswa baik dari segi pengetahuan maupun kemampuan berpikir siswa.

Model pembelajaran $P O E$ yang dapat mewadahi siswa untuk menjalankan aktifitas-aktifitas berpikir kognitif melalui metode ilmiah-metode tentunya lebih efektif dalam meningkatkan keterampilan proses sains. Siswa yang memiliki keterampilan metakognitif tinggi akan lebih cepat dan lebih baik dalam mengolah dan memanfaatkan kognisinya sehingga dapat berkontribusi pada peningkatan keterampilan proses sainsnya.

Hasil uji Tukey pada kelompok siswa yang memiliki keterampilan metakognitif tinggi, diperoleh Qhitung sebesar 8,79 sedangkan Qtabel sebesar 3,68 pada taraf signifikansi 0,05 . Ternyata nilai Qhitung> Qtabel sehingga $\mathrm{H}_{0}$ ditolak dan $\mathrm{H}_{1}$ diterima. Ini berarti bahwa pada siswa yang memiliki keterampilan metakognitif tinggi, rata-rata gains skor keterampilan proses sains siswa yang mengikuti POE lebih baik daripada yang mengikuti pembelajaran konvensional. Sedangkan hasil uji Tukey pada kelompok siswa yang memiliki keterampilan metakognitif rendah, diperoleh Qhitung sebesar 3,17 sedangkan Qtabel sebesar 3,68 dengan taraf signifikansi 0,05. Ternyata nilai Qhitung < Qtabel sehingga Ho diterima dan $\mathrm{H} 1$ ditolak. Ini berarti bahwa pada siswa yang memiliki keterampilan metakognitif rendah, rata- 
rata gain skor keterampilan proses sains siswa yang mengikuti POE tidak jauh berbeda dibandingkan yang mengikuti pembelajaran konvensional.

Model pembelajaran $P O E$ memberi-kan peluang kepada siswa yang memiliki keterampilan metakognitif tinggi untuk bisa mengeksplorasi keterampilan yang dimilikinya. $P O E$ memberikan peran yang lebih besar kepada mereka untuk memahami materi dan menemukan jawabannya sendiri melalui kegiatan penyelidikan. Dengan demikian, pembela-jaran menjadi lebih bermakna karena secara langsung melibatkan siswa dalam kegiatan-kegiatan ilmiah yang dapat mengembangkan keterampilan proses sains mereka.

Sementara itu, jika siswa yang memiliki keterampilan metakognititf tinggi diajarkan menggunakan model pembelajar-an konvensional yang berpusat pada guru, maka dimungkinkan akan menimbulkan kejenuhan bagi mereka. Karena pada dasarnya mereka hanya menerima pelajaran sebatas apa yang diajarkan oleh guru. Pembelajaran tidak dapat membuat mereka untuk mengkonstruks pengetahuannya sendiri dan mereka tidak mempunyai kesempatan dalam mengeksplorasikan diri secara optimal sehingga keterampilan proses sains yang mereka punyai tidak dapat berkembang secara maksimal.

Sebaliknya pada siswa yang memiliki keterampilan metakognitif rendah yang dibelajarkan dengan model pembelajaran $P O E$ akan membuat mereka menjadi tertekan dalam mengikuti pelajaran karena pada model pembelajaran $P O E$ siswa dituntut untuk selalu berpikir menggunakan kognisinya. Siswa dihadapi dengan masalah-masalah yang diberikan dan kemudian diharuskan untuk menyampaikan hipotesisnya. Hipotesis itu lalu dibuktikan melalui kegiatan bereksperimen. Dalam pembelajaran seperti itu, siswa dituntut untuk lebih aktif dalam menggunakan kognisinya serta aktif berkomunikasi dengan siswa yang lain dalam berdiskusi. Siswa yang memiliki keterampilan metakognisi rendah yang cenderung pasif akan lebih suka mengikuti langkah-langkah belajar yang teratur dan jelas karena mereka umumnya menerima materi pelajaran cenderung apa adanya, tidak dilakukan dengan menghubungkan antara konsep awal dan konsep alternatif yang lebih ilmiah. Mereka lebih terbiasa dengan belajar menghafal dan pembelajaran tanpa tekanan. Sehingga apabila diajarkan dengan model pembelajaran yang menggunakan pendekatan konstruktivisme serta berbasiskan permasalahan tentu akan menyulitkan bagi mereka.

Sementara itu, apabila siswa yang memiliki keterampilan metakognitif rendah diberikan pembelajaran konvensional yaitu pembelajaran yang berpusat pada guru. Dengan mekanisme pembelajaran yang hanya memberikan sedikit tekanan, membuat mereka merasa lebih rileks dan tenang. Pembelajaran yang terbimbing dengan guru sebagai sumber belajar utama menjadi pilihan model pembelajaran yang tepat bagi mereka. Kondisi pembelajaran seperti ini memacu mereka untuk berprestasi.

\section{KESIMPULAN DAN SARAN}

Berdasarkan hasil analisis dan temuan penelitian diatas dapat disimpulkan bahwa :

Pertama, terdapat perbedaan yang signifikan keterampilan proses sains antara siswa yang mengikuti pembelajaran dengan model pembelajaran POE dan siswa yang mengikuti pembelajaran secara konvensional. Keterampilan proses sains siswa yang mengikuti pembelajaran dengan model pembelajaran POE lebih baik daripada siswa yang mengikuti pembelajaran secara konvensional.

Kedua, terdapat pengaruh interaksi yang signifikan antara model pembelajaran POE dan keterampilan metakognitif terhadap keterampilan proses sains siswa.

Ketiga, pada siswa yang memiliki keterampilan metakognitif tinggi, terdapat perbedaan signifikan keterampilan proses sains antara siswa yang mengikuti pembelajaran dengan model pembelajaran POE dan siswa yang mengikuti pembelajaran konvensional. Keterampilan proses sains siswa yang memiliki keterampilan metakognitif tinggi yang mengikuti pembelajaran dengan model pembelajaran POE lebih baik daripada siswa yang mengikuti pembelajaran konvensional.

Keempat, pada siswa yang memiliki keterampilan metakognitif rendah, tidak terdapat perbedaan signifikan keterampilan proses sains antara siswa yang mengikuti pembelajaran dengan model pembelajaran POE dan siswa yang mengikuti pembelajaran konvensional. Pada kelompok siswa yang memiliki keterampilan metakognitif rendah, tidak terdapat perbedaan keterampilan proses sains antara siswa yang mengikuti pembelajaran dengan model pembelajaran POE dan siswa yang mengikuti pembelajaran konvensional.

Beberapa saran terkait dengan penelitian ini adalah sebagai berikut. Pertama, kepada guru-guru, terutama guru kelas dalam mengajar IPA untuk menggunakan model pembelajaran POE, karena dengan penerapan pembelajaran ini dapat menumbuhkan keterampilan metakognitif dan keterampilan proses sains siswa. Selain itu, guru juga harus mengidentifikasi tingkat keterampilan metakognitif siswa Dengan mengetahui tingkat keterampilan metakognitif siswa maka guru dapat menentukan model pembelajaran yang tepat dan efektif bagi siswa. Kedua, Model pembelajaran POE perlu dikenalkan dan dikembangkan lebih lanjut kepada para guru, siswa dan praktisi pendidikan lainnya sebagai salah satu alternatif pembelajaran. Proses pengenalan dan pengembangan model pembelajaran POE dapat dilakukan melalui seminar pembelajaran IPA, pertemuan KKG atau pelatihan-pelatihan pembelajaran. 


\section{DAFTAR PUSTAKA}

[1] Wahyuni, S E dkk. 2013. Pembelajaran Biologi Model POE (Prediction, Observation, Explain) Melalui Laboratoriumrill dan Laboratorium Virtuil Ditinjau dari Aktivitas Belajar dan Kemampuan Berpikir Abstrak. Jurnal Inkuiri Vol.2 No.3 2013. Surakarta: Universitas Sebelas Maret.

[2] Nuraini, N dkk. 2014. Pengembangan Modul Berbasis POE (Predict, Observe, and Explain) Disertai Roundhouse Diagram untuk Memberdayakan Keterampilan Proses Sains dan Kemampuan Menjelaskan Siswa Kelas X SMA Negeri 5 Surakarta. Jurnal Bio-Edukasi Vol.7 No.1. Surakarta: Universitas Sebelas Maret.

[3] Toharudin, dkk. 2011. Membangung Literasi Sains Peserta Didik. Bandung :Humaniora.

[4] Suma, K. 2010. Efektivitas Pembelajaran Berbasis Inkuiri Dalam Peningkatan Penguasaan Konten dan Penalaran Ilmiah Calon Guru Fisika. Jurnal Pendidikan dan Pengajaran Vol. 43 No.1. Singaraja: Universitas Pendidikan Ganesha.

[5] Rezba, RJ.,.Sprague C.R., McDonnough, TJ.,\& Matkins, JJ. 2006. Learning \& Assessing Science Process Skills, Fifth Edition. USA: Hunt Publishing.

[6] BSNP. 2007. Permendiknas No. 41 Tahun 2007 tentang Standar Proses. Jakarta: Depdiknas.

[7] Martin, M O dkk. 2015. TIMSS 2015: International Results in Science. Boston: TIMSS \& PIRLS International Study Center.

[8] Indriani. 2016. Peringkat PISA Indonesia Alami Peningkatan. http://www. antaranews.com/berita/600165/ peringkat-pisaindonesia-alami-peningkatan. Diakses pada tanggal 18 Januari 2016.

[9] Sari, M. 2012. Usaha Mengatasi Problematika Pendidikan Sains di Sekolah dan Perguruan Tinggi. Jurnal Al-Ta'lim jilid 1 No.1. Padang: IAIN Imam Bonjol.

[10] Napitupulu, E L. 2012. Prestasi Sains dan Matematika Indonesia Menurun. http://edukasi.kompas.com/read/2012/12/14/09005434/ Prestasi.Sains.dan.Matematika. Indonesia.Menurun. (diakses tanggal 4 Februari 2017).

[11] Woolfolk, A. 2009. Educational Psychology: Active Learning Edition. Yogyakarta: Pustaka Pelajar.

[12] Schunk, D H. 2012. Learning Theories: an Educational Perspective. Yogyakarta: Pustaka Pelajar.

[13] Suparno, P. 2013. Metodologi Pembelajaran Fisika Konstruktivistik dan Menyenangkan. Yogyakarta: Penerbit Universitas Sanatha Dharma.

[14] White, R. \& Gunstone, R. (1992). Prediction-observationexplanation. In: $R$ White and $R$ Gunstone (eds), Probing Understanding, ( $p p$ 44-64). London: The Falmer Press.

[15] Restami, M.P., Suma, K., \& Pujani, M. 2013. Pengaruh Model Pem-belajaran POE (Predict, Observe and Explaint) Terhadap Pemahaman Konsep Fisika dan Sikap Ilmiah Ditinjau dari Gaya Belajar Siswa. E-journal Program Pascasarjana Universitas Pendidikan Ganesha Vol.3 2013.

[16] Simons,P.R.J. 1996. Metacognition in E. De Corte \& F.E Weinert (Eds). International Encyclopedia of Developmental and Instructional Psychology. Oxford, UK: Elsevier Science.

[17] Flavell, J.H. 1976. Metacognitive Aspects of Problem Solving In L.B. The Nature of Intelligence. Hillsdale, NJ: Erlbaum. 